\title{
Comparative SEM study regarding the performance of 4th generation of dental adhesives and universal adhesives
}

\author{
Studiu SEM comparativ privind performanțele adezivilor dentari generația a IV-a și \\ adezivii universali
}
Ştefan George Călinoiu, Cornelia Bîcleşanu, Anamaria Florescu, Alexandru Burcea, Ştefan Manea

Facultatea de Medicină Dentară, Universitatea „Titu Maiorescu“, Bucureşti, România

\begin{abstract}
REZUMAT
Scopul acestui studiu este de a compara generaţia a VIII-a de adezivi universali cu cei de generaţia a IV-a, consideraţi "standardul de aur" din punctul de vedere al puterii de adeziune, adaptării marginale şi a grosimii stratului de adeziv. Material şi metodă. Studiul s-a efectuat pe un lot de 40 dinţi extraşi în scop ortodontic/parodontal. Aceştia au fost împărţiţi în 4 loturi de lucru a câte 10 dinţi. Pe fiecare dinte s-au efectuat cavități clasa I care interesează atât smalțul, cât și dentina, urmate de obturarea cavităților cu materiale adezive și de restaurare diferite, astfel: pentru lotul $1 \mathrm{~s}$-a folosit adezivul Clearfil + rășină compozită Gradia, pentru lotul $2 \mathrm{~s}$-a folosit adezivul Clearfil + ormocerul Admira, pentru lotul 3 s-a folosit adezivul All Bond 3 + rășină compozită Gradia, iar pentrul lotul 4 s-a folosit adezivul All Bond $3+$ ormocerul Admira. După efectuarea restaurărilor conform protocolului de lucru, cu respectarea indicaţiilor producătorilor, dinții au fost secționați în sens vestibulo-oral cu ajutorul unui disc de piesă dreaptă, sub jet de apă, secțiunile rezultate incluzând zona restaurării, precum și smalțul și dentina cu care aceasta vine în contact. Secțiunile au fost analizate cu ajutorul microscopului electronic de baleiaj Quanta Inspect. În urma analizei secţiunilor la microscopul electronic, s-au evidenţiat grosimea stratului de adeziv, adeziunea la ţesuturile dentare (smalţ şi dentină) şi adeziunea la cele 2 materiale de restaurare.

Rezultate şi discuții. În loturile de lucru 1 şi 2 în care a fost folosit adezivul universal Clearfil, stratul de adeziv este de aproximativ $10 \mathrm{~nm}$, fără a avea o grosime regulată, aceasta variind între 5 şi $15 \mathrm{~nm}$. De asemenea, se pot observa neregularităţi în interfaţa dintre ţesutul dentar şi prezenţa unor goluri de aer. În stratul de adeziv universal Clearfil, hibridizarea este una slabă comparativ cu cea obținută în stratul adeziv de generaţia a IV-a.

În loturile de lucru 3 şi 4, pentru care s-a folosit adezivul All Bond 3 (adeziv de generaţia a IV-a în 3 timpi, cu etapa de gravare acidă separată), grosimea adezivului este aproximativ $40 \mathrm{~nm}$, fără goluri de aer, compactă, păstrânduse relativ constantă chiar şi în zonele dificile ale cavităţii. Hibridizarea este net superioară în cazul adezivului de generaţia a IV-a, iar interfaţa dintre ţesutul dentar şi adeziv este una uşor crenelată, ceea ce măreşte suprafaţa de contact. Mărirea suprafeţei de contact şi lipsa golurilor oferă adezivului în 3 timpi (generaţia a IV-a) o adaptare marginală mult mai bună comparativ cu cea a adezivului universal.

Concluzii. Adezivul universal Clearfil prezintă o adeziune inferioară sistemului All Bond datorită diferenței de aderare de la interfața adeziv-țesut dentar, unde gravajul acid și bondingul din sistemul All Bond realizează legături mai puternice.
\end{abstract}

Cuvinte cheie: adezivi universali, generaţia a IV-a, bonding, adeziune

ABSTRACT
The aim of this study is to compare, in terms of adhesion strength, marginal adaptation, and thickness of the adhesive
layer, the 8th generation of adhesive systems with those of the 4th generation which are considered the "golden standard".
Materials and method. The study was performed on a batch of 40 teeth extracted for periodontal/orthodontic reason.
They were divided into 4 groups of 10 teeth each. Class I preparation which interested both enamel and dentin were
performed on each tooth. The preparations were restored using adhesive systems and restoration materials as follows:
group 1: Clearfil Universal Bond Quick, Kuraray Noritake Dental Inc. adhesive system + composite resin Gradia direct
posterior, GC; group 2: Clearfil Universal Bond Quick, Kuraray Noritake Dental Inc adhesive system+ ormocer Admira
Fusion, VOCO; group 3: All Bond 3, Bisco adhesive + composite resin Gradia direct posterior, GC; group $4:$ All Bond
3, Bisco + ormocer Admira Fusion, VOCO. After performing the restorations according to the working protocol and in
compliance with the manufacturer's instructions, the teeth were sectioned in the facio-lingual direction using a diamond
disc and water cooling. The resulting sections include the restoration area, as well as the enamel and the dentin in the
vicinity.The sections were analyzed using Quanta Inspect scanning electron microscope. Following the SEM analysis
of the sections, the thickness of the adhesive layer, the adhesion to the dental tissues (enamel and dentin), as well as
the adhesion to the restoration materials were highlighted.
Results and discussions. In 1 and 2 working groups, in which the Clearfil Universal Bond Quick, Kuraray Noritake
Dental Inc. was used, the adhesive layer is approximately 10 nm, with a thickness that varies between 5 and 15 nm.




\begin{abstract}
Also irregularities at the interface with the dental tissue and the presence of air voids can be observed. With Clearfil Universal Bond Quick adhesive layer, hybridization is weak compared to that obtained with the 4th generation adhesive layer. In 3 and 4 working groups, All Bond 3, Bisco adhesive system was used (4th generation adhesive system, Etchand-Rinse 3-step (ER 3-step), with separate acid etching step). The thickness of the adhesive layer is about $40 \mathrm{~nm}$, without air voids, the area is compact, relatively constant even in difficult areas of the cavity. With the 4th generation adhesive system, the hybridization is clearly superior, and the interface between the dental tissue and the adhesive is slightly creased, which increases the contact surface. The increased contact surface and the lack of air voids ensure the ER 3-step adhesive system a much better marginal adaptation compared to the universal adhesive.

Conclusions. Clearfil Universal Bond Quick, universal adhesive system shows a weaker adhesion compared to All Bond 3 adhesive system due to the difference of adhesion at the adhesive- dental tissue interface, where the acid etching and bonding of All Bond 3 system ensure stronger bonds.
\end{abstract}

Keywords: universal adhesive system, 4th generation adhesive, bonding, adhesion strength

\section{INTRODUCERE}

Introducerea și dezvoltarea materialelor compozite pentru restaurarea leziunilor coronare dentare a determinat apariția, pe parcursul evoluției și înțelegerii procesului de adeziune, a unui număr mare de materiale implicate în acest proces. Când vorbim de materiale, ne referim la răşinile compozite, dar și la sistemele adezive necesare tehnicii de restaurare.

În plus, apariţia conceptului de terapie minimum invazivă, care presupune sacrificiul minim de substanță dentară pentru orice tip de restaurare, se bazează pe eficacitatea adezivilor actuali smalț-dentină.

Sistemele adezive s-au dezvoltat începând din anii '90 în direcția creșterii capacităţii de adeziune, dar și a simplificării tehnicilor de aplicare.

Generaţia a IV-a de adezivi dentinari a introdus demineralizarea cu acid fosforic, tehnica realizându-se în 3 etape succesive. Această metodă este considerată ,standardul de aur“ deoarece rezultatele arată performanțele clinice realizate în timp prin aplicarea ei. Există însă și critici care se referă la posibilitatea apariției complicațiilor și eșecurilor determinate de numărul etapelor necesare aplicării, precum și prezenței etapei de spălare.

Generațiile ulterioare s-au orientat către aceasta direcție, respectiv reducerea pașilor pentru aplicarea componentelor sistemului adeziv. Adezivii dentari au evoluat de la sistemele de demineralizare totală (a IV-a și a V-a generație) la sisteme de autogravare (a VI-a, a VII-a generație). Adeziunea la substraturile dentare se bazează pe strategii diferite de aplicare, fie demineralizare şi clătire, fie autogravare a structurilor dentare.

A VIII-a generație de adezivi a apărut în 2010, prin introducerea adezivului Futurabond DC (Voco America), care conține nanoparticule cu o dimensiune medie a particulelor de $12 \mathrm{~nm}$. Această structu- ră crește puterea de penetrare a monomerilor din răşină și a grosimii stratului hibrid, ceea ce îmbunătăţește proprietăţile mecanice ale sistemelor adezive, inclusiv reducerea contracției de polimerizare. Dimensiuni mai mari de $15-20 \mathrm{~nm}$ ale acestor particule sau creșterea în greutate cu peste $1 \%$ a umpluturii pot crește vâscozitatea adezivilor și pot provoca acumulări ale umpluturii în partea superioară a suprafeței umezite. Aceste defecte pot induce fisuri și pot determina o scădere a rezistenței legăturii adezive [1].

Adezivii universali sau multifuncţionali pot folosi ambele strategii de adeziune, precum și tehnica demineralizării totale sau selective. Astfel, pot fi folosiți ca adezivi autogravanți (SE), adezivi cu demineralizare și clătire (ER) sau ca adezivi autogravanți (SE) pe dentină şi adezivi cu demineralizare și clătire (ER) pe smalț (demineralizare selectivă a smalțului) [1].

Această nouă generație versatilă de adeziune pledează pentru utilizarea celei mai simple opțiuni a fiecărei strategii, adică aplicarea adezivilor autogravanți (SE) într-o etapă şi aplicarea adezivilor cu demineralizare (ER) în două etape, folosind aceeași soluție adezivă uniflacon, ceea ce este mult mai dificil pentru aplicarea pe substraturile dentare de diferite compoziții.

Generația adezivilor universali se aplică prin tehnici simplificate și uşor de utilizat cu orice strategie de adeziune și oferă versatilitatea utilizării cu o varietate de materiale de restaurare directe și indirecte [2].

La ora actuală, piața materialelor de restaurare adezivă directă este invadată de o multitudine de produse aparţinând unor multitudini de firme care își promovează produsele ca fiind cele mai performante.

Scopul acestui studiu este de a efectua o comparație între modul în care se realizează adeziunea la structurile dentare (smalț, dentină) obținută prin acțiunea sistemelor adezive de generația a IV- 
a, considerată încă „standardul de aur“, și ultima generație de adezivi, adezivii universali.

\section{MATERIAL ŞI METODĂ}

Studiul s-a realizat pe un lot de 40 dinți extrași, care, după extracție, au fost curăţaţi și depozitați în apă distilată.

Am împărțit dinții extrași în 4 loturi/grupuri de lucru a câte 10 dinţi.

Pe fiecare dinte s-au efectuat cavități clasa I, atât ce interesează smalțul, cât și dentina, urmate de obturarea cavităților cu materiale adezive și de restaurare diferite, astfel:
- Lot 1 - adezivul Clearfil + rășină compozită Gradia

- Lot 2 - adezivul Clearfil + ormocerul Admira

- Lot 3 - adezivul All Bond 3 + rășină compozită Gradia

- Lot 4 - adezivul All Bond 3 + ormocerul Admira

Dinţii au fost fixați în arcade dentare artificiale. Pentru restaurare au fost folosite rășini compozite și ormoceri, iar pentru adeziune s-au aplicat sisteme adezive din generații diferite, cu respectarea protocolului de lucru și indicațiile producătorilor (tabelele 1, 2, 3).

TABELUL 1. Schema de repartizare a materialelor pe grupele de studiu

\begin{tabular}{|l|l|l|l|l|}
\hline & Grup 1 & Grup 2 & Grup 3 & Grup 4 \\
\hline Sistem adeziv & $\begin{array}{l}\text { Clearfil Universal Bond } \\
\text { Quick, Kuraray Noritake } \\
\text { Dental Inc. } \\
\text { (SE 1-step) }\end{array}$ & $\begin{array}{l}\text { Clearfil Universal Bond } \\
\text { Quick, Kuraray Noritake } \\
\text { Dental Inc. } \\
\text { (SE 1-step) }\end{array}$ & $\begin{array}{l}\text { All Bond 3, Bisco } \\
\text { (ER 3-step) }\end{array}$ & $\begin{array}{l}\text { All Bond 3, Bisco } \\
\text { (ER 3-step) }\end{array}$ \\
\hline Material restaurator & $\begin{array}{l}\text { Gradia Direct Posterior, GC } \\
\text { (rășină compozită) }\end{array}$ & $\begin{array}{l}\text { Admira Fusion, VOCO } \\
\text { (ormocer) }\end{array}$ & $\begin{array}{l}\text { Gradia Direct Posterior, GC } \\
\text { (rășină compozită) }\end{array}$ & $\begin{array}{l}\text { Admira Fusion, VOCO } \\
\text { (ormocer) }\end{array}$ \\
\hline
\end{tabular}

TABELUL 2. Protocol de aplicare a sistemului adeziv

\begin{tabular}{|l|l|}
\hline Sistem adeziv & Protocol aplicare \\
\hline $\begin{array}{l}\text { Clearfil Universal Bond } \\
\text { Quick, Kuraray Noritake } \\
\text { Dental Inc. }\end{array}$ & $\begin{array}{l}\text { Se aplică cu peria aplicatoare cu o mișcare de frecare pe întregul perete al cavității. Nu este necesar timp } \\
\text { de așteptare. } \\
\text { Atentie! Saliva sau exsudatul nu trebuie să contacteze suprafețele tratate } \\
\text { Se usucă ușor } 5 \mathrm{sec} \text {, se fotopolimerizează [3]. }\end{array}$ \\
\hline All Bond 3, Bisco & $\begin{array}{l}\text { 1. Demineralizare timp de } 15 \text { secunde folosind și clătire. } \\
\text { 2. Îndepărtați excesul de apă folosind o peletă de spumă sau aspirație, lăsând preparatul vizibil umed. } \\
\text { 3. Se amestecă număr egal de picături de All Bond } 3 \text { părți A și B (1:1) într-un godeu. } \\
\text { 4. Folosind o perie, se amestecă adezivul timp de } 5 \text { secunde. } \\
\text { 5. Se aplică 1-2 straturi pe întreaga preparație timp de 5-10 secunde. } \\
\text { 6. Se usucă timp de } 5 \text { secunde, apoi se usucă bine timp de cel puțin } 10 \text { secunde. Suprafața ar trebui să } \\
\text { pară strălucitoare; în caz contrar, se aplică strat suplimentar. } \\
\text { 7. Opțional: fotopolimerizare ușoară timp de } 10 \text { secunde. } \\
\text { 8. Se plasează materialul de restaurare [4]. }\end{array}$ \\
\hline
\end{tabular}

TABELUL 3. Protocol de aplicare a materialelor restauratoare

\begin{tabular}{|c|c|}
\hline \multicolumn{2}{|c|}{ Material restaurator } \\
\hline $\begin{array}{l}\text { Gradia direct } \\
\text { posterior, GC }\end{array}$ & $\begin{array}{l}\text { Matricea: uretandimetacryilat (UDMA), dimetacrilat camforchinonă } \\
\text { Umplutura: fluoro-alumino-silicat pudră de sticlă de siliciu. } \\
\text { 1. Selectarea nuanței. } \\
\text { 2. Prepararea cavității și crearea unui câmp de lucru uscat. } \\
\text { 3. Adeziune cu Clearfil sau All Bond. } \\
\text { 4. Plasare compulă cu vârf aplicator - direct în cavitate. } \\
\text { 5. Modelare înainte de fotopolimerizare folosind tehnici standard. } \\
\text { 6. Fotopolimerizare cu lampa Elipar (3 M- ESPE), intensitate luminoasă } 1.200 \mathrm{~mW} / \mathrm{cm} 2 \text {, timp de polimerizare } 5 \text { secunde. } \\
\text { 7. Finisare și lustruire; lustruite cu discuri de polizat (Sof-lex, } 3 \text { M ESPE). }{ }^{[2]}\end{array}$ \\
\hline $\begin{array}{l}\text { Admira } \\
\text { Fusion, } \\
\text { voco }\end{array}$ & $\begin{array}{l}\text { Matricea: răşină Ormocer } \\
\text { Umplutură: silicon oxid nanoparticule, particule de ceramică de sticlă }(1 \mu \mathrm{m}) \\
\text { 1. Selectarea nuanței. } \\
\text { 2. Izolarea - Crearea unui câmp de lucru uscat. } \\
\text { 3. Aplicarea materialului adeziv - în cazul nostru Clearfil sau All Bond } 3 . \\
\text { 4. Aplicarea Admira Fusion straturi de maximum } 2 \mathrm{~mm} \text {, urmată de fotopolimerizare. } \\
\text { 5. Fotopolimerizarea } 20-40 \text { secunde în funcție de culoarea folosită. } \\
\text { 6. Finisarea. }\end{array}$ \\
\hline
\end{tabular}


Materialele au fost aplicate în straturi de $2 \mathrm{~mm}$ grosime, întâi pe peretele vestibular şi extins oblic pe peretele ocluzal, apoi pe peretele oral și extins oblic pe peretele ocluzal, în final ultimul strat reface morfologia ocluzală. Fiecare strat este fotopolimerizat 20-40 sec. conform indicațiilor producătorilor, dinspre vestibular/oral şi apoi dinspre ocluzal. La final, restaurările sunt finisate și lustruite.

După restaurare, dinții au fost secționaţi în sens vestibulo-oral cu ajutorul unui disc de piesă dreaptă, sub jet de apă, secțiunile rezultate incluzând zona restaurării, precum și smalțul și dentina cu care aceasta vine în contact.

În continuare, sunt prezentate imagini reprezentative din timpul realizării protocolului de lucru pentru preparare și secționarea dinților.

\section{Grup 1: Adeziv Clearfil și Gradia Direct Posterior GC (fig. 1, 2, 3, 4)}

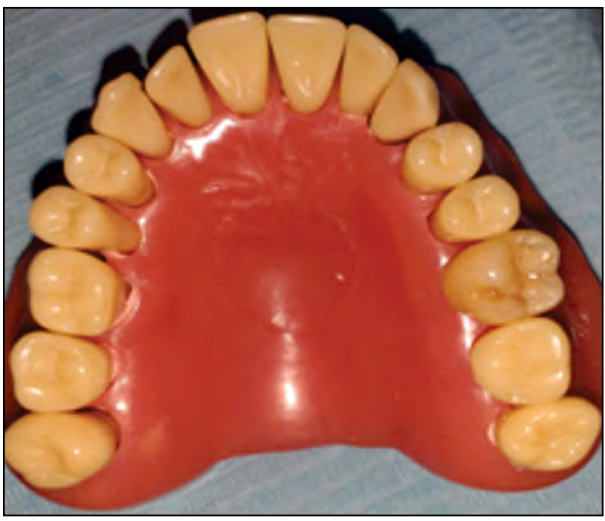

FIGURA 1. Dintele fixat pe arcadă

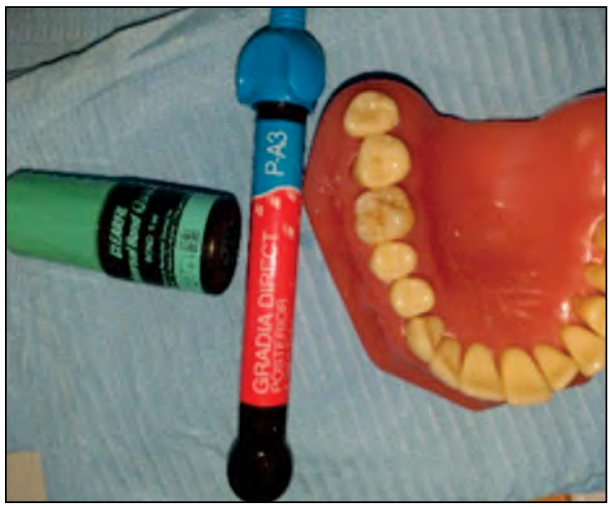

FIGURA 2. Materialele folosite

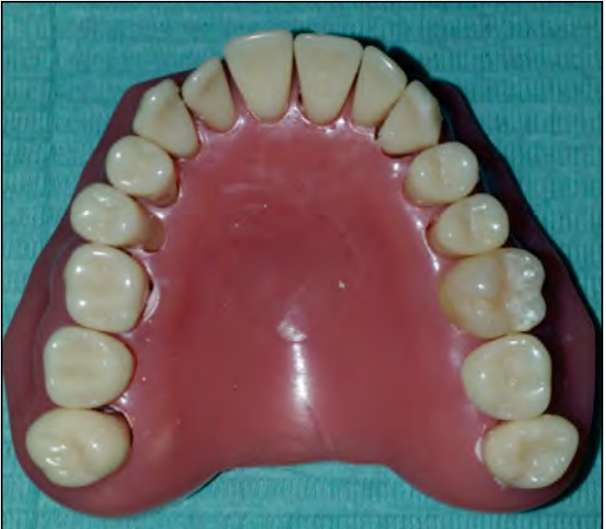

FIGURA. 3. Aspect final restaurație

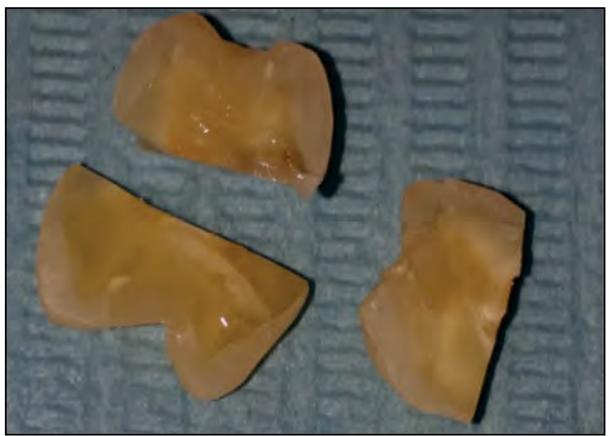

FIGURA 4. Secțiunile pentru analiză SEM

Grup 2: Clearfil și Admira Fusion

(fig. 5 a,b, 6, 7)

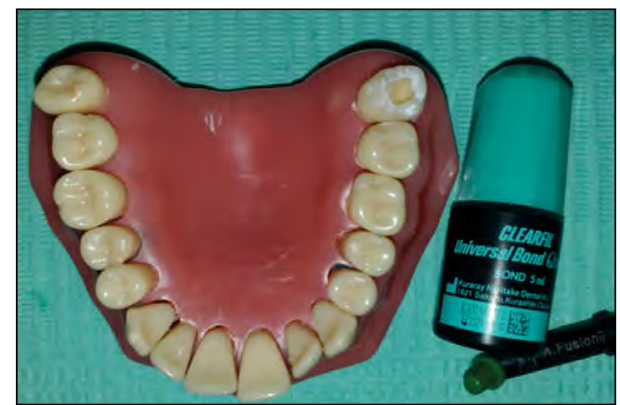

a

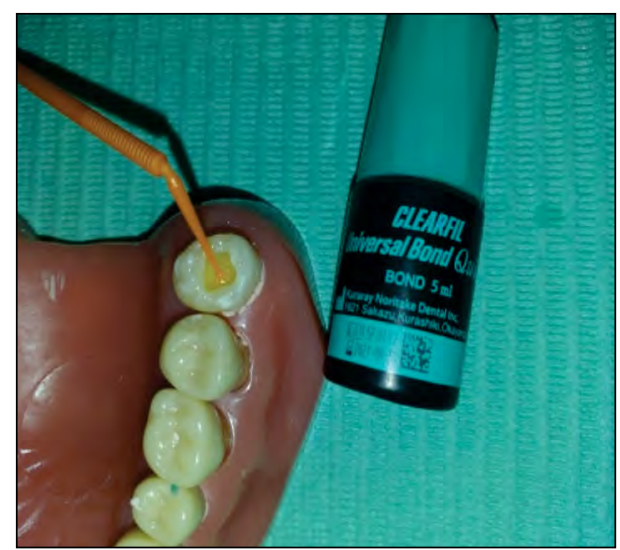

b

FIGURA 5A. Dintele fixat în arcada artificială cu preparația+ materialele folosite; b.aplicare adeziv 


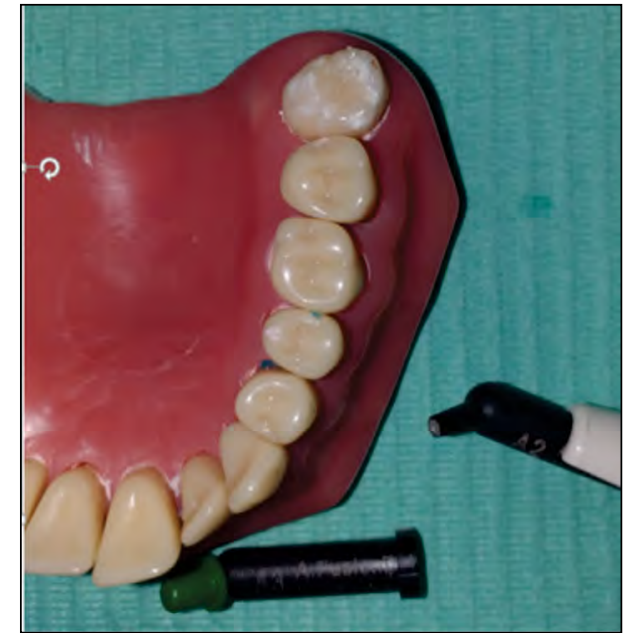

FIGURA 6. Aspect final restaurare

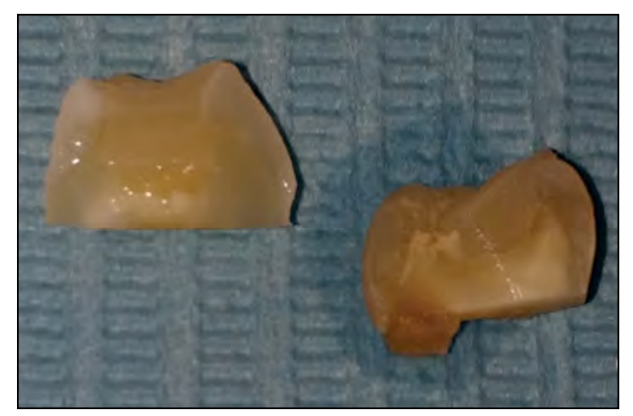

FIGURA 7. Secțiunile pentru analiza SEM

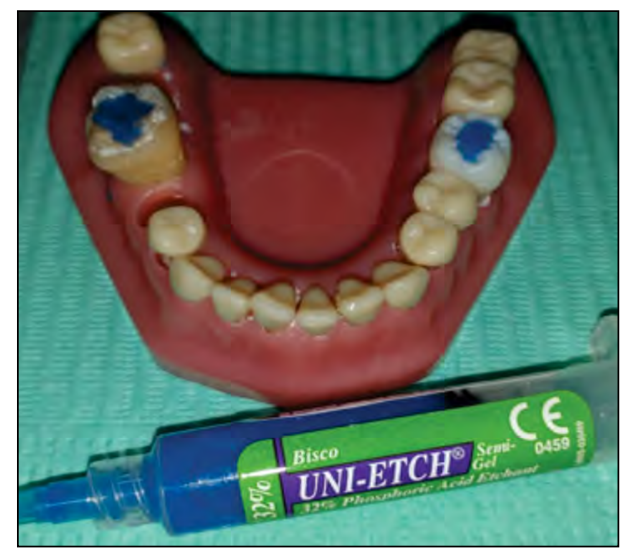

a

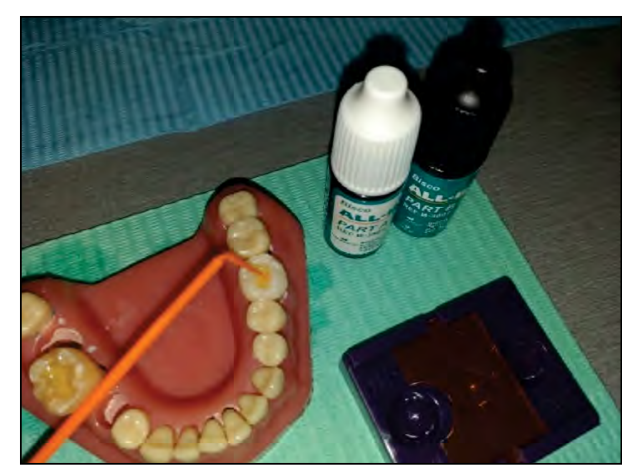

c

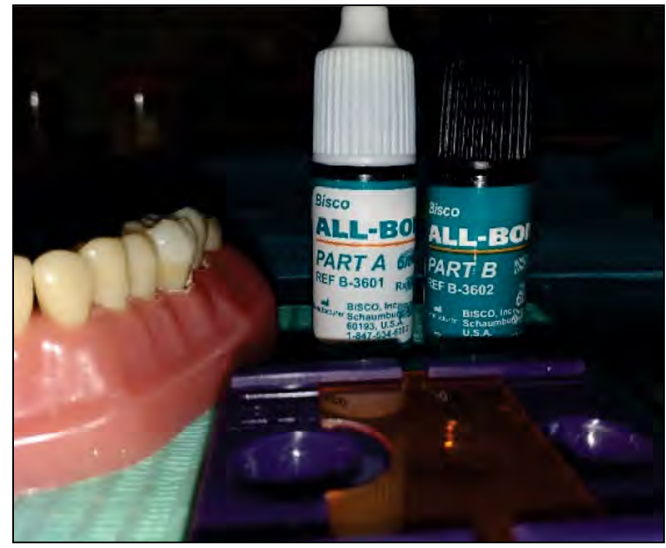

b

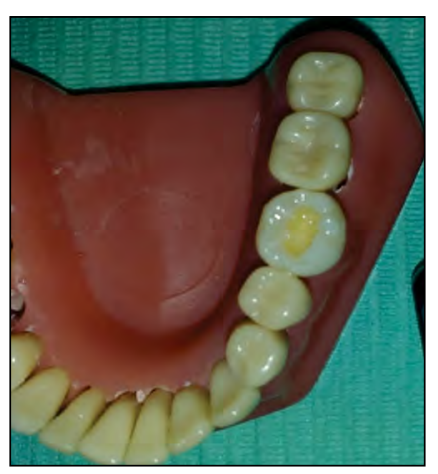

d
Grup 3: All Bond 3 și Gradia Direct Posterior (fig. 8, 9 a,b,c,d, 10, 11)

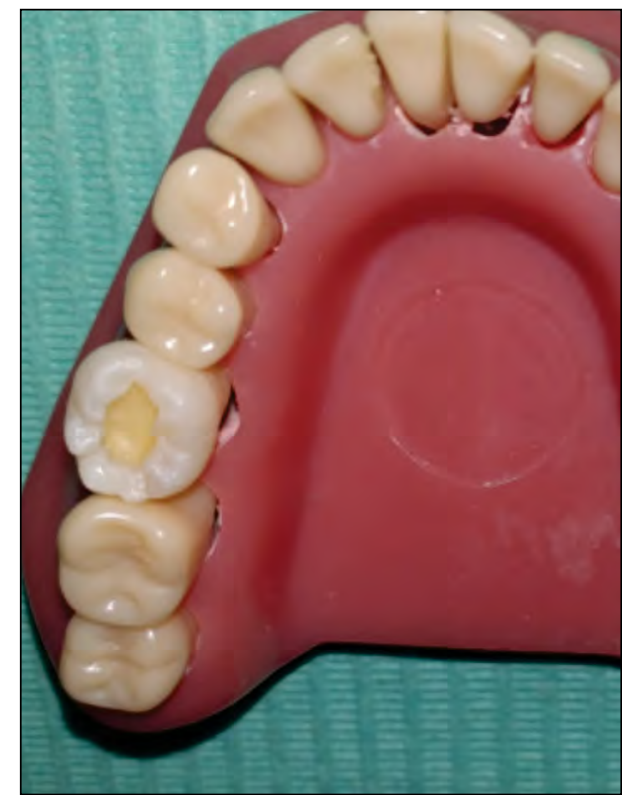

FIGURA 8. Dinte în arcada artificială cu preparația
FIGURA 9. Materialele folosite conform protocolului, etape de lucru a: demineralizare, $b$, c: bonding utilizat, aplicare bonding; $d$ : aspect preparație post aplicare bonding 


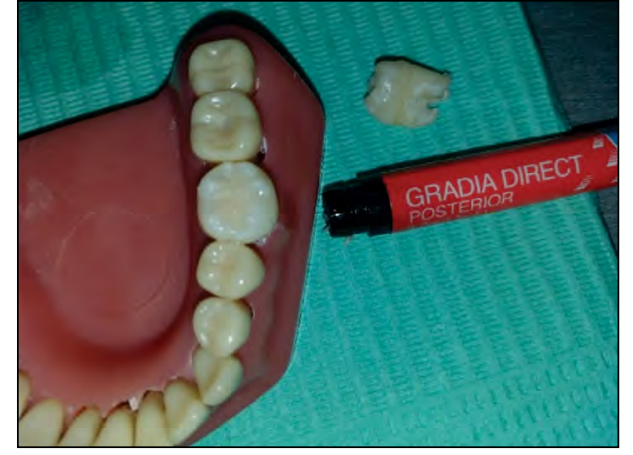

FIGURA 10. Aspect final restaurare

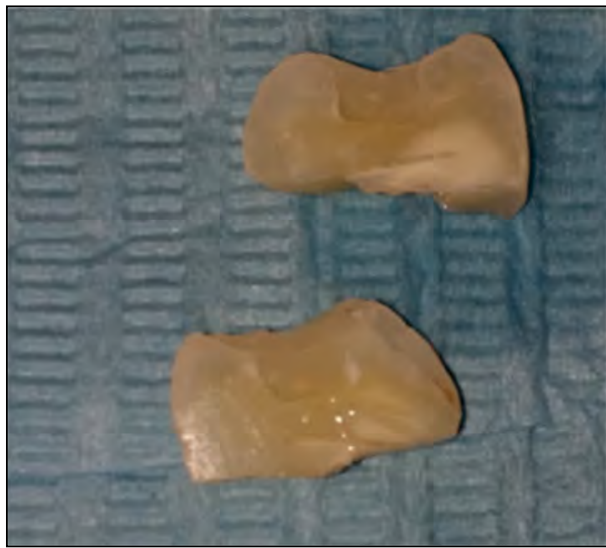

FIGURA 11. Secțiunile pentru analiza SEM

Grup 4: All Bond 3 și Admira Fusion (fig. 12, 13, 14, 15)

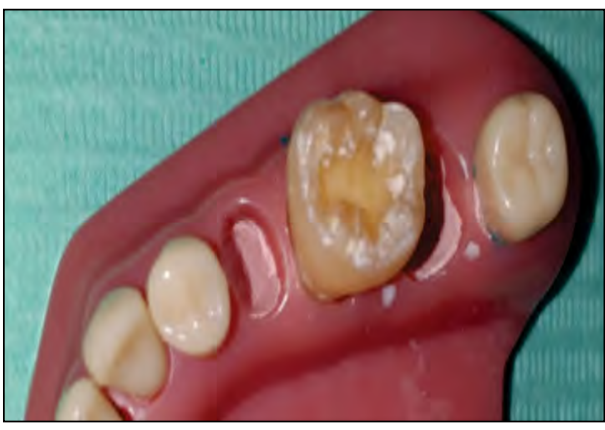

FIGURA 12. Dinte în arcada artificială

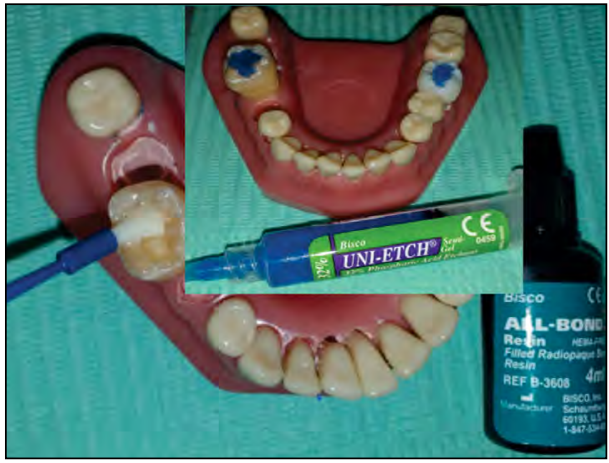

FIGURA 13. Materialele folosite

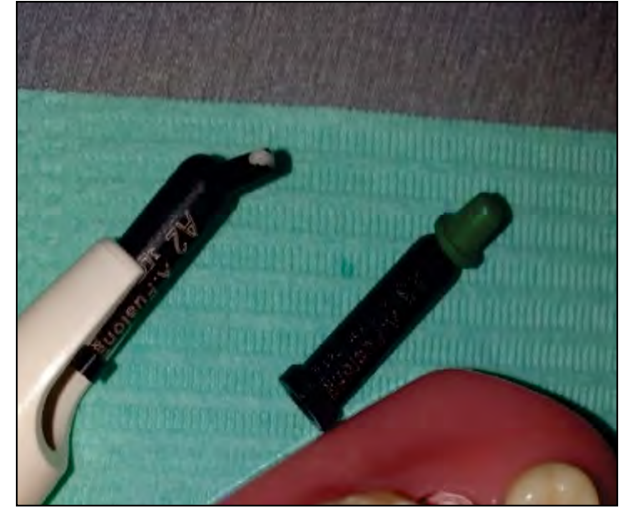

FIGURA 14. Aspect restaurare finală

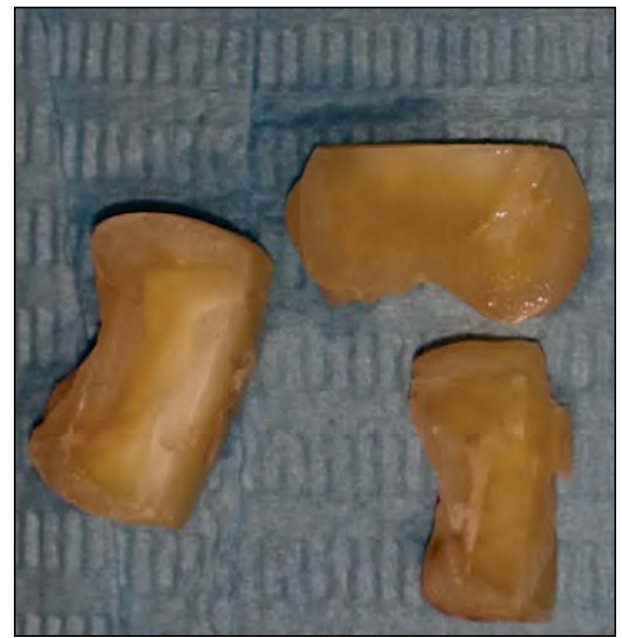

FIGURA 15. Secțiunile pentru analiza SEM

\section{PREPARAREA DINTTILOR PENTRU ANALIZA SEM}

Secțiunile, păstrate în apă distilată, au fost fixate pe un suport de aluminiu de tip STAB și acoperite cu un strat de aur de $9 \mathrm{~nm}$ pentru efectuarea conductivității. Investigarea probelor s-a efectuat $\mathrm{cu}$ ajutorul microscopului electronic de baleiaj Quanta Inspect F cu rezoluţie de 1,2 nm și spectometru de raze $\mathrm{X}$ dispersiv în energie (EDS) cu rezoluția la $\mathrm{MnK}$ de $133 \mathrm{eV}$.

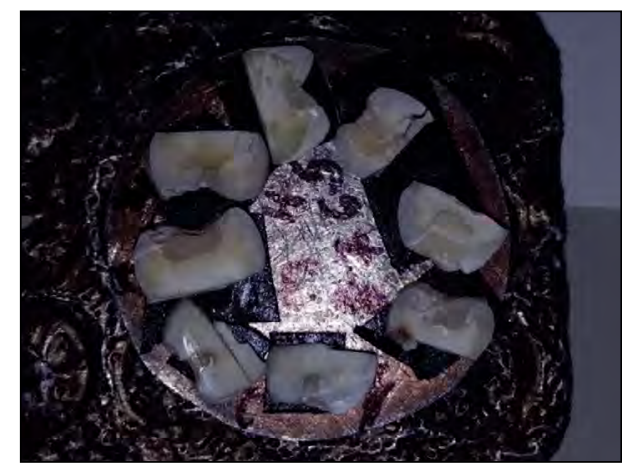

FIGURA 16. Secțiunile pregătite pentru analiza SEM 


\section{REZULTATE}

Imaginile SEM obținute pentru cele 4 grupuri analizate sunt prezentate în figurile următoare.

\begin{tabular}{|c|c|}
\hline \multicolumn{2}{|c|}{$\begin{array}{c}\text { Grup 1 } \\
\text { Clearfil Universal Bond Quick, Kuraray Noritake Dental Inc. (SE 1-step) și Gradia Direct } \\
\text { Posterior, GC }\end{array}$} \\
\hline Adeziunea la smalț & \\
\hline 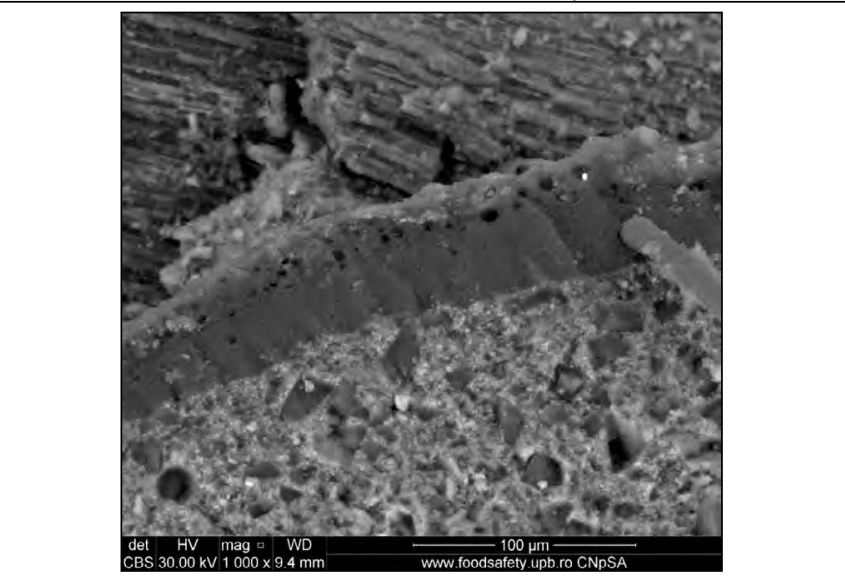 & \\
\hline $\begin{array}{l}\text { FIGURA 17. Interfața restaurare-adeziv-smalț, mag. } 1.000 \text { x } \\
\text { Se remarcă o adeziune foarte bună între sistemul adeziv } \\
\text { și materialul de restaurare; prismele smalțului au cape- } \\
\text { tele demineralizate. Stratul de adeziv, deși are grosime } \\
\text { uniformă, prezintă spre complexul hibridizat-smalț o } \\
\text { structură neomogenă (probabil goluri de aer, datorate } \\
\text { lipsei de omogenizare a adezivului). La interfața ade- } \\
\text { ziv-smalţ se remarcă complexul hibridizat. }\end{array}$ & $\begin{array}{l}\text { Stratul de adeziv aderă foarte bine la materialul } \\
\text { de restaurare și se pare că și la dentină. Linia de } \\
\text { fractură care apare în dentină (probabil din cau- } \\
\text { za modalitații de secționare a dintelui) nu permite } \\
\text { aprecierea cu exactitate a adeziunii în acestă zonă, } \\
\text { dar în imagine se observă prezența unui complex } \\
\text { hibridizat bine reprezentat. }\end{array}$ \\
\hline
\end{tabular}

\begin{tabular}{|c|c|}
\hline \multicolumn{2}{|c|}{$\begin{array}{c}\text { Grup } 2 \\
\text { Clearfil Universal Bond Quick, Kuraray Noritake Dental Inc. (SE 1-step) și Admira Fusion, } \\
\text { VOCO }\end{array}$} \\
\hline Adeziune la smalt & \begin{tabular}{|c|} 
Adeziune la dentină \\
\end{tabular} \\
\hline 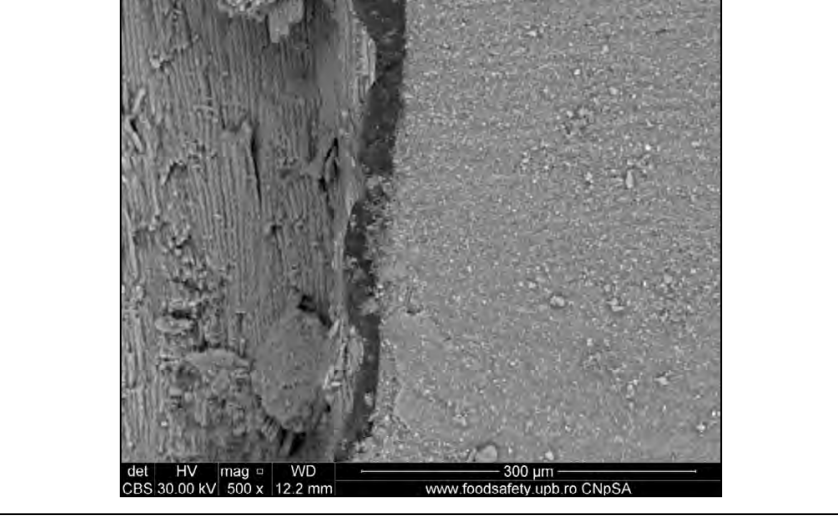 & \\
\hline $\begin{array}{l}\text { FIGURA 19. Interfața restaurare-adeziv-smalt, mag. } 500 x \\
\text { Se remarcă o adeziune foarte bună între sistemul } \\
\text { adeziv și materialul de restaurare, stratul de adeziv } \\
\text { are o grosime relativ uniformă. La interfața adeziv- } \\
\text { smalț se observă zone de complex hibridizat. }\end{array}$ & $\begin{array}{l}\text { FIGURA 20. Interfața restaurare-adeziv-dentină, mag. } 1.000 \text { x } \\
\text { Se observă o adeziune foarte bună atât la interfaţa } \\
\text { adeziv-material de restaurare, cât și la interfața } \\
\text { adeziv-dentină. Stratul de adeziv are grosime } \\
\text { uniformă și structură omogenă, fără goluri de aer. }\end{array}$ \\
\hline
\end{tabular}




\begin{tabular}{|c|c|}
\hline \multicolumn{2}{|c|}{$\begin{array}{c}\text { Grup 3 } \\
\text { All Bond 3, Bisco (ER 3-step) și Gradia Direct Posterior, GC }\end{array}$} \\
\hline Adeziune la smalt & Adeziune la dentină \\
\hline $\mid \begin{array}{ll}\text { del } \\
\text { del } \\
\text { CBS }\end{array}$ & 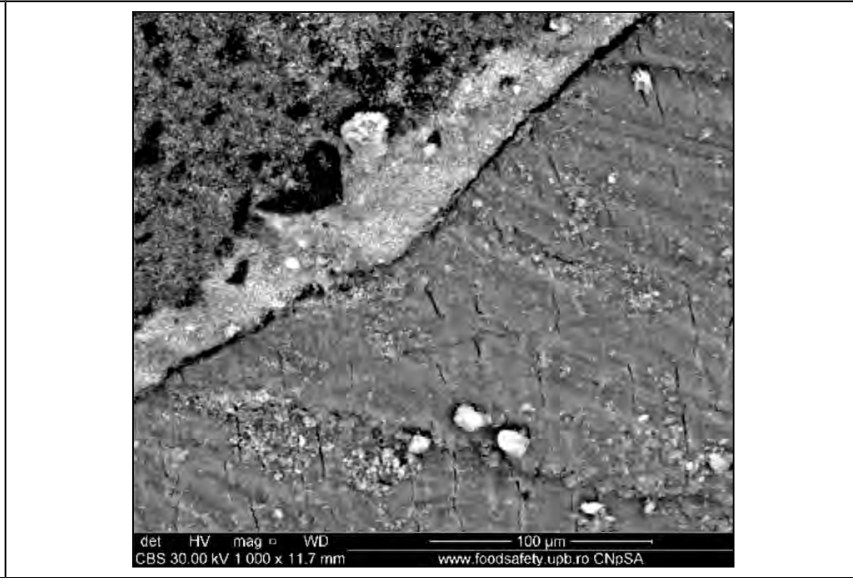 \\
\hline $\begin{array}{l}\text { FIGURA 21. Interfața restaurare-adeziv-smalț, mag. } 2.000 \text { x } \\
\text { Se observă o interfaţă adezivă,,perfectă““, cu prisme } \\
\text { de smalț cu capete demineralizate și microretenții, } \\
\text { un strat hibrid clar, adezivul are structură omogenă } \\
\text { și grosime uniformă. }\end{array}$ & $\begin{array}{l}\text { FIGURA 22. Interfața restaurare-adeziv-dentină, mag. } 1.000 x \\
\text { Se observă o adeziune foarte bună atât la interfața } \\
\text { adeziv-material de restaurare, cât și la interfața } \\
\text { adeziv-dentină. Stratul de adeziv are grosime } \\
\text { uniformă și structură omogenă, fără goluri de aer. }\end{array}$ \\
\hline
\end{tabular}

\begin{tabular}{|c|c|}
\hline \multicolumn{2}{|c|}{$\begin{array}{c}\text { Grup } 4 \\
\text { All Bond 3, Bisco (ER 3-step) și Admira Fusion, VOCO }\end{array}$} \\
\hline Adeziune la smalt & $\begin{array}{l}\text { Adeziune la dentină } \\
\end{array}$ \\
\hline 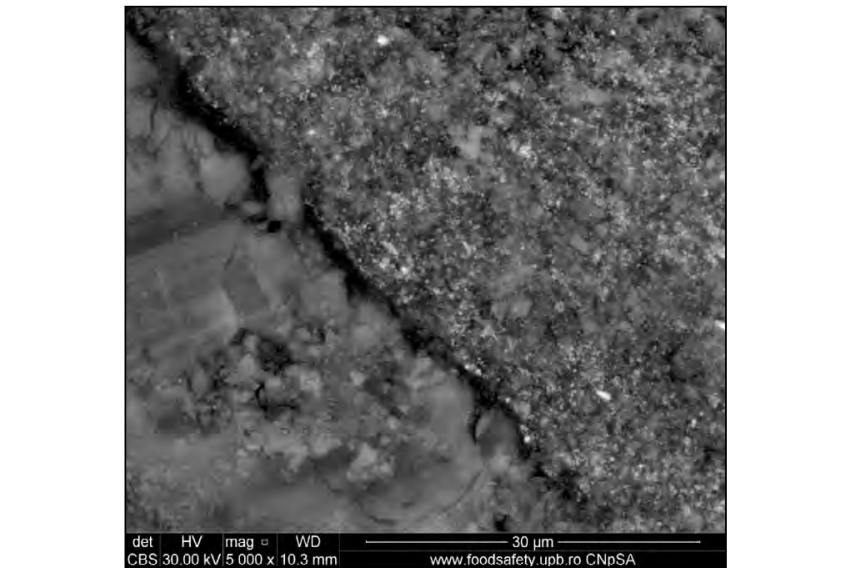 & (2) \\
\hline FIGURA 23. Interfața restaurare-adeziv-smalț, mag. $5.000 x$ & FIGURA 24. Interfața restaurare-adeziv-dentină, mag. $2.000 x$ \\
\hline $\begin{array}{l}\text { Se observă o adeziune foarte bună între sistemul } \\
\text { adeziv și materialul de restaurare, stratul de adeziv } \\
\text { are o grosime uniformă și structură omogenă, } \\
\text { stratul hibrid este clar. }\end{array}$ & $\begin{array}{l}\text { Adeziune ,perfectă“ la nivelul dentinei; se observă } \\
\text { stratul de adeziv și stratul hibrid, precum și cepurile } \\
\text { de rășină care pătrund în canaliculele dentinare. În } \\
\text { imagine apar și fine linii de fractură, datorate, cel } \\
\text { mai probabil, metodei de secționare a dintelui. }\end{array}$ \\
\hline
\end{tabular}

\section{DISCUȚII}

În acest studiu am analizat comparativ adeziunea la stucturile dentare dure (smalț și dentină) a unor sisteme adezive din generaţii diferite, respectiv generația a IV-a şi ultima generație de adezivi.
A fost analizat modul în care s-a realizat această adeziune, cu aprecierea prezenței golurilor, care arată o adeziune deficitară, precum și a grosimii și uniformității straturilor adezive. 
Sistemele adezive din generaţia a IV-a reprezintă prima categorie de adezivi care a utilizat sistemul de demineralizare a țesuturilor dure dentare. Deși ele folosesc aplicarea în 3 timpi, considerată astfel „consumatoare“ de timp, totuși unele studii arată că ea reprezintă „standardul de aur“" pentru tehnicile adezive.

Ultima generație de adezivi, denumiţi „,universali“, este considerată cea mai versatilă deoarece utilizează aplicarea adezivilor autogravanți (SE) într-o etapă și aplicarea adezivilor cu demineralizare (ER) în două etape, folosind aceeaşi soluţie adezivă uniflacon.

Studiul nostru a dorit să demonstreze care dintre aceste două generaţii este mai performantă din punct de vedere clinic și în ce măsură compoziția structurii dentare şi tipul materialului de restaurare influențează acest proces.

În cadrul folosirii sistemului adeziv Clearfil, observăm adeziunea deficitară a adezivului Clearfil la dentină în lipsa gravajului acid. Deficiența se observă în imaginile ce prezintă joncțiunea dintre material și țesut dentar, în care se pot observa spații unde adezivul este desprins de țesutul dentar.

De asemenea, se observă cum țesutul dentar în zona joncțiunii este neted și regulat fără a oferi o retentivitate fermă. Adezivul Clearfil nu prezintă grosime constantă şi este bine delimitat atât de țesutul dentar, cât și de materialul de umplutură. Interferează cu straturile vecine doar în suprafaţă, la limita de contact.

Gradia, ca material de obturație, apare în imagini ca un material omogen, cu porozități fine și care poate copia fidel pereții cavității.

Admira este un material de umplutură omogen, fără porozităţi considerabile, prezentând densități uniforme și constante.

În cadrul grupurilor ce au folosit sistemul adeziv All Bond 3, observăm adeziunea fermă la dentină și smalț a adezivului All Bond în prezența gravajului acid.

Adeziunea dintre material și țesut dentar prezintă microretentivităţi în urma gravajului acid, aşadar, adeziunea este crescută comparativ cu tehnica fără gravaj acid.

De asemenea, se observă cum țesutul dentar în zona joncțiunii este ușor neregulat şi oferă o retentivitate fermă. Adezivul prezintă grosime constantă și interferează cu stratul de țesut dentar superficial.
În acord cu rezultatele studiului nostru, studiul in vitro realizat de VOCO GmbH, în 2015, ne arată rezultatele foarte bune ale adezivului Clearfil SE Bond, cu valori ale adeziunii de până la 55-60 MPa. Dar condițiile clinice sunt diferite, deci studiile in vivo nu prezintă aceleași rezultate foarte bune, pierzând teren în faţa adezivilor de generaţia a IV-a [6].

În urma studiului clinic realizat de Apostolide D şi colab., s-a observat că adeziunea cea mai bună la smalț s-a realizat prin tehnica de gravare totală în 3 timpi, în timp ce cea mai slabă adeziune a prezentat sistemul adeziv autogravant într-un singur timp. Astfel, s-a arătat că cea mai bună sigilare marginală se obține printr-o gravare acidă separată, așa cum introducerea etapei de gravare acidă separată a îmbunătățit semnificativ valorile sigilării marginale a adezivilor autogravanți [7].

Studiul recent realizat de Cuevas-Suárez CE şi colab. a evaluat dacă performanța de adeziune a adezivilor universali este influenţată de gravajul acid. Rezultatele obținute sugerează că puterea adeziunii este dependentă de $\mathrm{pH}$, astfel că adezivii universali, deși cu performanțe ridicate similare adezivilor în 3 timpi, necesită un mediu ,ideal“ pentru a obține aceste bune performanțe de adeziune. În concluziile studiului, recomandarea este a se folosi gravajul acid selectiv al smalțului în utilizarea adezivilor universali. Așadar, studiul a confirmat faptul că adezivii universali prezintă performanțe similare celor de generația a IV-a doar în medii şi condiții ideale de lucru ce uneori sunt greu de realizat în practica din cabinetul stomatologic [8].

Aceleași rezultate au obținut Bacelar-Sá R și colab., care, în studiul lor clinic, arată că, după analiza la 24 ore și 6 luni a restaurărilor realizate cu adezivi universali și de generația a IV-a, adezivul universal prezintă o adeziune similară adezivului de generația a 4-a, dar, din punctul de vedere al microinfiltrațiilor marginale, adezivul de generația a IV-a a avut rezultate $\mathrm{cu} 10-15 \%$ mai bune [9].

În studiul realizat de Jang Ji-Hyun și colab., sunt comparate aceleaşi sisteme adezive Clearfil şi All Bond. Concluziile studiului, în dezacord cu rezultatele studiului nostru, arată că adezivul universal, în ciuda tehnicii de folosire simplificate, a prezentat o bună adeziune la țesuturile dure dentare, cu ușoare deficiențe în cazul cavităţilor atipice [10].

Studiile efectuate de Kuraray Co.Ltd în vederea demonstrării eficienței adezivului Clearfil în cadrul 
lansării adezivului în 2015, în care probele au fost supuse temperaturilor extreme $4^{\circ}-60^{\circ}$ și a 4.000 cicluri de forțe de diferite amplitudini, au arătat că adezivul Clearfil, comparativ cu adezivii de generație a IV-a, oferă performanțe similare din punctul de vedere al adeziunii și implică un mod de utilizare mult mai simplificat [11].

Legat de grosimea stratului adeziv, studiul nostru arată că grosimea stratului adezivilor universali este mai mică (aproximativ 5-15 nm) şi variabilă, în timp ce grosimea stratului adezivilor de generaţia a IV-a este mai mare (aproximativ $40 \mathrm{~nm}$ ) și aproximativ constantă.

În studiul realizat de Ji-Hyun Jang din 2016, s-au obținut rezultate similare referitoare la grosimea stratului adeziv în urma analizei la microscopul TEM, respectiv $10 \mathrm{~nm}$ în cazul adezivilor universali și respectiv $40 \mathrm{~nm}$ în cazul adezivilor de generaţia a IV-a. Așadar, grosimea stratului de adeziv nu influențează puterea de lipire a adezivilor, dar o grosime mai mare poate anula unele defecte ale suprafeței cavității [10].

\section{BIBLIOGRAFIE}

1. Sofan $\mathrm{E}$ et al. Classification review of dental adhesive systems: from the IV generation to the universal type. Ann Stomatol (Roma). 2017 Jan-Mar; 8(1):1-17.

2. Nagarkar S, Theis-Mahon N, Perdigão J. Universal dental adhesives: Current status, laboratory testing, and clinical performance. J Biomed Mater Res B Appl Biomater. 2019 Aug;107(6):2121-2131.

3. AllBond 3, Instructions for Use, from Bisco, 2018.5; https://www. bisco.com/assets/1/22/All_Bond_3_English2.pdf.

4. Clearfil Universal Bond Quick, Kuraray Dental, 2018.12, Brochure how to use; https://kuraraydental.com/wp-content/uploads/2018/12/ clearfil-universal-bond-quick-new-cap-brochure-sm.pdf.

5. Gradia Direct Posterior Clinical Guide, 2010, GC; https://cdn. gceurope.com/v1/PID/gradiadirect/manual/MAN_Gradia_Direct_ Clinical Guide en.pdf.

6. Admira Fusion - Tensile bond strength values ,VOCO, 2015.10; https://www.voco.dental/us/portaldata/1/resources/products/ scientific-reports/us/admira-fusion_scr_tensile-bond-strength-values_ gb.pdf.

7. Apostolide D, Pomohaci DD, Radu TM, Uliuliuc A, Andrian S. Evaluarea sigilării marginale a restaurărilor cervicale din răşini

\section{CONCLUZII}

Adezivul universal Clearfil prezintă o adeziune inferioară sistemului All Bond datorită diferenței de aderare de la interfața adeziv-țesut dentar, unde gravajul acid și bondingul din sistemul All Bond realizează legături mai puternice.

Grosimea stratului adezivilor universali este mai mică (aproximativ 5-15 nm) și variabilă, în timp ce grosimea stratului adezivilor de generația a IV-a este mai mare (aproximativ $40 \mathrm{~nm}$ ) și aproximativ constantă.

Hibridizarea este net superioară în cazul adezivului de generaţia a IV-a, iar interfaţa dintre ţesutul dentar şi adeziv este una uşor crenelată, ceea ce măreşte suprafaţa de contact. Mărirea suprafeței de contact şi lipsa golurilor de aer oferă adezivului în 3 timpi (generaţia a IV-a) o adaptare marginală mult mai bună comparativ cu cea a adezivului universal.

\section{Notă}

Toţi autorii au contribuţie egală la elaborarea acestui studiu de cercetare.

compozite realizate prin diferite tehnici adezive. Medicina Stomatologică 2007, 11:1.

8. Cuevas-Suárez CE, da Rosa WLO, Lund RG, da Silva AF, Piva E. Bonding Performance of Universal Adhesives: An Updated Systematic Review and Meta-Analysis. J Adhes Dent. 2019; 21(1):7-26.

9. Bacelar-Sá R, Giannini M, Ambrosano GMB, Bedran-Russo AK. Dentin Sealing and Bond Strength Evaluation of Hema-Free and MultiMode Adhesives to Biomodified Dentin. Braz Dent J. 2017 Nov-Dec;28(6):731-737.

10. 1Ji-Hyun Jang, Myoung Geun Lee, Sang Uk Woo, Chung Ok Lee, Jin-Kyu Yi, Duck-Su Kim. Comparative study of the dentin bond strength of a new universal adhesive. Dental Materials Journal 2016.35:4:606-12.

11. Clearfil Universal Bond Quick, Kuraray Dental, Tehnical informations and scientific product information, 2019.07; https://www. kuraraynoritake.com/world/product/adhesives/pdf/universal_bond_ brochure.pdf; https://www.kuraraynoritake.eu/pub/media/pdfs/ clearfil-universal-bond-quick-scientific-product-information-en.pdf. 